\title{
SPOLUPRÁCE ROBERTA SMETANY A BEDŘICHA VÁCLAVKA V KONTEXTU MÍSTA A DOBY. ÚRYVKY Z JEDNÉ ŽIVOTNÍ KAPITOLY
}

V rámci širšího povědomí o povšechném kulturním dění ve městě Olomouci ve 20. století je Robert Smetana (1904-1988) obecně znám jako muzikolog, folklorista, univerzitní profesor, organizátor a kritik, muzejní pracovník, znalec olomouckých památek a vášnivý fotograf. Badatelské počátky Roberta Smetany nalezneme v Brně, kde rok studoval nejdříve na přírodovědecké fakultě a následně hudební vědu, kterou absolvoval v roce 1929 ve třídě Vladimíra Helferta. Předmětem jeho zájmu se stal lidový zpěv - respektive doktorské studium ukončil prací s názvem $\mathrm{O}$ melodických idiotismech v lidovém zpěvu evangelíků velkolhoteckých. ${ }^{1}$ Bedřich Václavek (1897-1943) přišel do Brna po studiích v Praze, Vídni a Berlíně. Působil zde zprvu jako učitel 1. státního reálného gymnázia na Starém Brně. Od roku 1924, do doby přeložení do Olomouce, byl knihovníkem Zemské a univerzitní knihovny v Brně.

Okolnosti vzniku spolupráce mezi Robertem Smetanou a Bedřichem Václavkem spadají překvapivě už do roku 1910. Robert Smetana ve svých vzpomínkách uvádí, že v roce 1910 zjistil František Homolka² zlidovění některých umělých básní a písní a svá zjištění publikoval v Zíbrtově Českém zpěvu. ${ }^{3}$ V roce 1920 pak upozornil prof. Jan Jakubec, ${ }^{4}$ tehdy svého posluchače, Bedřicha Václavka na Homolkovy zápisy a zadal Václavkovi na toto téma řadu studijních úkolů. Od roku 1924 pak Václavek rozpracovával projekt Českých světských písní zlidovělých. O této jeho koncepci byla informována odborná veřejnost a to nejen

1 Termín „idiotismech“ značí zastaralou podobu slova „,idiomech“.

2 František Homolka (1885-1933) pocházel se slavné houslařské rodiny Homolků. Byl učitelem ve Zlosyni a sběratel lidových písní, které jsou uloženy v Ústavu pro etnografii a folkloristiku Akademie věd.

HOMOLKA, František. Rozšíření písní umělých mezi lidem českým. Český lid, 1911, r. 20, s. 31-41.

4 Jan Jakubec (1862-1936) byl český literární historik a kritik. V letech 1919-1932 působil jako profesor dějin české literatury na Filozofické fakultě Univerzity Karlovy. 
obecně, ale také monografiemi o jednotlivých zlidovělých písních. Vladimír Helfert pak v této věci učinil to, že informoval svého posluchače Roberta Smetanu, který se podobné problematice věnoval. Spolupráce mezi oběma vědci pak započala v 1930 a pokračovala i v době, kdy byl Václavek v Olomouci a Smetana v Brně. ${ }^{5}$

Brno bylo pro Roberta Smetanu městem vědeckých a umělecko-kritických začátků. I přes možnosti, které město nabízelo, byl Smetana od roku 1932 bez stálého zaměstnání (od roku 1935 byl stipendistou ministerstva školství, pro podporu nezaměstnané inteligence). Sporadicky vystupoval v rozhlasových relacích či pořádal archiválie v Janáčkově archivu. ${ }^{6}$ Tento stav, pochopitelně, komplikoval Smetanovi život. Ve svých dopisech se Václavkovi svěřoval s tíživou životní situací. Bedřich Václavek ho pak mnohokrát přesvědčoval, aby Brno opustil a přestěhoval se za ním do Olomouce. ${ }^{7}$ I Smetana chápal vzdálenost Brna a Olomouce, pro současnou i budoucí spolupráci, jako komplikaci. Osobní komunikace mezi Václavkem a Smetanou byla totiž omezena pouze na pár sobot v měsíci, na pravidelné korespondenční lístky a dopisy. Smetana se však k odchodu do Olomouce, města, které neměl rád a necítil $\mathrm{v}$ něm potenciál, neměl. $\mathrm{V}$ níže uvedeném textu přikládáme dopis Bedřicha Václavka z 12. března 1934.

„Milý přiteli! Přemýšlím pořád o Vás a po zralém uvážení (a vzteku na všelijaké pány) Vám dělám tento návrh: 1) zbavte se nějak svého brněnského bytu a to bud', že jej pronajmete is nábytkem nebo vủbec pustite a nábytek si někde lacino uskladnite. 2) nastěhujte se prozatím na 3 mèsíce - $k$ nám i budete zadarmo bydlet, stravovat se a v pokojiku pro služku (jinak byste pracoval v mé pracovně v Studijni knihovně). 3) Musil byste si opatřovat jen penize na to své (neštastné) pojištěni a vedlejši výdaje, což byste snadno udělal napsáním několika článkì.[...]“8

$5 \quad$ Z tohoto období se dochovala bohatá korespondence, která je uložena v pozůstalosti Roberta Smetany v Archivu Národního muzea v Praze a v nezpracované pozůstalosti Bedřicha Václavka v Památníku národního písemnictví v Praze. Až dramaticky se pak utvářel odchod, resp. útěk Václavka z Olomouce. Dne 3. dubna 1940 opustil Bedřich Václavek Olomouce a odešel do ilegality (gestapu unikl přes Moravské Slovácko do Prahy). Již 10. května měl pak být v Olomouci zatčen. Za Václavka, který již v tu dobu byl mimo Olomouc, byla zatčena jeho žena Jaroslava Václavková a vězněna do 5. června 1940 ve věznici tzv. Amtsgerichtu v Olomouc. 30. dubna 1942 večer byl Bedřich Václavek - tehdy již opět žijící v Praze pod jménem František Hrdina - v bytě akademického sochaře Zdeňka Dvořáka v Praze na Letné v Schnirchově ulici č. 15 na schůzce komunistických kulturních pracovníků zatčen gestapem a uvězněn na Pankráci. Ve čtvrtek 28. ledna 1943 byl František Hrdina (resp. Václavek) transportem převezen do koncentračního tábora v Osvětimi. V únoru 1943 onemocněl skvrnitým tyfem, koncem února byl převezen do karantény a zde, v pátek 5 . března $1943 \mathrm{v} 10$ hodin dopoledne v „Kasernengasse“ údajně zemřel.

6 Tyto činnosti byly ojedinělé. Rozhlasové relace se konaly jen párkrát do měsíce a honoráře, dle dochované korespondence, Smetanovy nechodily pravidelně. Výpomoc, resp. uspořádávání dokumentů v Janáčkově archivu, kterou získal díky Vladimíru Helfertovi, byla dočasná. Měsíčně si Smetana vydělal 500 Kč.

7 Václavek byl do Olomouce přeložen v roce $1933 \mathrm{z}$ trestu $-\mathrm{z}$ důvodu své komunistické činnosti v Brně.

8 Všechny dopisy přepsány bez úprav. Památník národního písemnictví Praha, fond Bedřich 
Dne 13. prosince 1935 Václavek obdržel tento dopis: „Milý príteli.

Budete dnes na mne asi nadávat. Chtěl bych tomu předejít opravdu jakkoli, ale nedaři se mi to. Říkal jsem Vám posledně v kavárně, že má situace je silně nahnutá. Tehdy jsem však ještě spoléhal, že seženu nějaké penize na fakultě. Domnival jsem se, dokonce, že vymámím všechno, co bude třeba. Ale V. H. ${ }^{9}$ mi dal jen ze svého, protože to ostatni nešlo, a to co jsem dostal bylo jen 200.- Ted' všude jinde jsou vánoce. A já na druhé straně nesmím nechat dojít věci tak daleko, aby byli obtěžováni ručitelé, natož pak, aby něco musili platit. Ani nevite, jak toužebně čekám na nějaké positivní zprávy z Olomouce a jak rychle bych byl $v O$. Vy víte sám, zda jsem nyní úvěruschopným. Bud'te tak laskav a přemýšlejte, zda byste mi nemohl pomoci. Uvažte, že jsem Vám toho dlužil už mnoho, a že jste dosud celkem ještě o nic nepřišel. A tenkráte jsem byl bez budoucnosti. Dnes bych snad potřeboval jen 160 Kč a tak laskavě o tom premýšlejte. Jde ovšem jen o to, máte-li nějaké penize uloženy. $Z$ hotového $v$ kapse bych toho od Vás ovšem nežádal. $[\ldots]^{\text {‘10 }}$

Smetana svoji situaci snášel obtížně. Mnohokrát ve svých dopisech nabízel Václavkovi výměnu spolupracovníka. Činil tak z důvodu, že byl nucen brát různé krátkodobé výpomoci, díky kterým však přestával mít čas na sběratelskou práci. Dne 7. června1934 Václavek napsal:

„Milý príteli!

Nevím, co Vás vlastně potkalo, že jste ztratil do té miry rovnováhu? Nemaje o tom ponètí, nemohu do věci naplno mluvit. Tuším, že jde o penize. Jde-li o penize na taxy, pak se to musí nějak spravit, proto byste prece věc neodkládal a nekazil si přes roku života, v němž můžete celou svou situaci, uděláte-li rigorosum, podstatně k lepšímu změnit. Bojím se však, že jde o nějaké Vaše skrupule, že při rigorosu nebudete excelovat nebo pod. Pamatujte, že [....] skvělými výsledky studuji studenti, kteři na to mají. U Vás je to otázka existence a ted' jde o to mit tu formalitu co nejdřive s krku! Jediná vážná překážka by byla, kdyby některý $z$ obou rozhodujicich examinátorì, $t$. j. Helfert nebo Souček najednou postavil přilišné požadavky, jimž byste musil vyhovět a proto ještě dlouho studovat. Doufám však, že o to nejde. Závěrem tohoto prvního odstavce Vás žádám, abyste mi určitě ještě zitra v pátek napsal přiloženým listem, oč vlastnějde. Vyzývám Vás už predem, abyste nepřerušoval studia. [...] Ale o tom až později. Zatím

1) Neberu na vědomí Vaši rezignaci ze spolupracovnictví

2) čekám obratem Vaši zprávu

3) věrim, že jedete plnou parou dál. [...]"“11

Václavek, nezpracovaná pozůstalost. Oddíl Smetana Robert.

9 Vladimír Helfert

10 Památník národního písemnictví Praha, fond Bedřich Václavek, nezpracovaná pozůstalost. Oddíl Smetana Robert.

11 Archiv Národního muzea Praha, fond Robert Smetana, k. 8, inv. č. 618, Václavek Bedřich 1932-1940. 
Hovory mezi Smetanou a Václavkem o možném přestěhování do Olomouce začaly nabývat většího významu v říjnu roku 1935 . V této době se totiž Václavkovi donesla informace o nabízeném místě v uměleckohistorickém oddělení Muzea Hlavního města Olomouce, dnes Vlastivědného muzea. Smetana zvažoval možnost přestěhování, ale do Olomouce se mu stále moc nechtělo. Dne 20. října 1935 proto píše Václavkovi.

„Milý priteli,

dnes ráno se mnou mluvil řed. Dr. Jar. Helfert ${ }^{12}$ a upozornil mne na misto, které vypisuje město Olomouc pro své městské museum. Jde o totéž misto, na které jste mne onehdy upozornil Vy na základě jakési novinové zprávy. Řed. Helfert mne prosil, abych o tom nikde nevypravoval a tak i já prosím o totéž Vás. Hned, jakmile jsem dostal Váš dopis s ústřižkem, ve kterém bylo toto misto oznámeno, rozmýšlel jsem se, zda by to nebylo něco pro mne. Ted'o tom, když jsem byl př́mo vybídnut, musím premýšlet opravdověji. Olomouc sama by se mi nezamlouvala, ale zvykl bych si na to. Ted' běži o to, zda by toto misto stálo za uváženou. Informujte se proto prosím o této věci ze všech stran. Řikejte, že mne na to chcete upozornit Vy a zda mi to máte doporučit. Vyzvéd'te laskavě také, jak by to bylo placeno. Zkrátka, napište mi všechno, co budete moci zvědět. A já bych to misto vzal, kdybyste Vy mi nakonec podepsal revers, že nepůjdete z Olomouce. Zároveň budu i já hovořit o tom s prof. Helfertem. Tak nezapomeňte na mne laskavě a napište mi o tom.

Srdečně Vás zdravím. Váš Rob. Smetana“13

Václavkova odpověd' pak přišla hned následující den 21. října 1935. Smetana však vyžadoval od Václavka záruku - resp. ho přímo žádal o podpis reversu, že neopustí Olomouc po čas jejich spolupráce. Václavek se ale tomuto „obchodu“ snažil vyhnout.

„Milý príteli!

Měl byste na začátku 800 Kč, ale šlo by to rychleji vpřed, než u státu. Kromě toho byste mohl vypomáhat nějakou hodinou ve Vlast. museu, ${ }^{14} z$ čehož byste měl taky něco. Postup bude časem upraven až do radoství. Na první vypsání se nikdo vhodný nepřihlásil (jen profesoři). Na druhé $p$. dr. Vyb. ${ }^{15}$ ještě neví okamžitě. Překážka by mohla být, kdyby se snad přihlásila zvláště odborně (t. j. archeologicky) kvalifikovaná sila. Kdybyste měl doporučeni od řed. Helferta (a snad ještě dr. Absolona, který je zde v kuratoriu), mohl byste to dostat (nenastane-li onen prípad s tím archeologem). Dr. Vyb. prý v tom má hodné slovo a tlačil by Vás (mohl jsem mu naznačit, o koho jde). Práce je prý tam málo. ((Kromě toho

12 Jaroslav Helfert (1883-1972) ředitel Moravského zemského muzea v Brně, zakladatel muzeologie na brněnské filozofické fakultě. Bratr muzikologa Vladimíra Helferta.

13 Památník národního písemnictví Praha, fond Bedřich Václavek, nezpracovaná pozůstalost. Oddíl Smetana Robert.

14 Vlastivědné muzeum Olomouc

15 PhDr. Bohuš Vybíral (1887-1951) překladatel a znalec jihoslovanské literatury, vysokoškolský pedagog, publicista a organizátor spolkového života. Od roku 1913 do roku 1948 působil ve Studijní knihovně v Olomouci (dnes Vědecká knihovna). 
se hodláme my stěhovat, tak bychom si najali byt o 4 pokojich, chtěl-li byste.)) ((A nehnuli bychom se z Olomouce, až bychom dodělali ty písničky.)) (((Nebo až bychom byli docenty?))) Všechno je to celkem dobré, existenci byste měl slušnou a pro soukromou véd. práci vhodnou. Jen jestli se odhodláte opustit Brno. Já Vám totiž ten revers, že Ol. neopustím, podepsat nemohu. Ale predstavte si tohle: Co když po roce, až se prestěhujeme do nové budovy, dr. Vyb. odešel, jak chce, a mně už ,důvěrovali ' na tolik, aby mi svěrili ř́zeni knihovny? Kdož ví, jestli bych odtud zrovna pospichal.

Vnaději, že bychom byli dva přednostové, zdravi Vás, těším se na Váš př́chod, ale nepřemlouvám

Váš B. $V$.

P. S. Byl byste zde jediným kvalifikovaným hud. kritikem! [...]"16

Robert Smetana nakonec místo v Muzeu hlavního města Olomouce získal a na pozici správce uměleckohistorického oddělení působil od roku 1936 do roku 1946.

Kooperace mezi Václavkem a Smetanou trvala přibližně do roku 1940, kdy byly práce na edici České světské písně zlidovělé přerušeny. Rukopisy byly rozděleny mezi oba spolupracovníky a sbírkový a dokumentační materiál pro edici lyrických písní zlidovělých byl deponován napřed v tehdejší Studijní knihovně a přibližně roku 1941 byl přemístěn do Státního ústavu pro lidovou píseň v Praze. Během okupace byl však Václavkův exemplár̆ rukopisu pro svazek epických písní zlidovělých ztracen. I tato skutečnost měla za důsledek, že se na edici zpracování Českých světských písní zlidovělých čekalo až do 2. poloviny padesátých let.

První polovina této nešt’astné doby byla pro Smetanu velmi náročná. Jednak $\mathrm{z}$ důvodu, že se chystal na habilitaci, ${ }^{17}$ tak především z důvodů okolností, které se v její souvislosti děly. Toto období totiž prožil velmi častými kádrovými výslechy a to převážně v souvislosti s Václavkem a jeho politickou př́slušností. Smetana se tak často cítil být vinen svým prátelstvím $\mathrm{k}$ němu, ale zároveň byl vystaven spekulacím, že si vzájemnou pracovní blízkost vymyslel a Václavka prakticky, pouze, využíval ke svému vědeckému růstu. Vysvětlení či potvrzení svých mylných dedukcí se pokoušel nalézt prostřednictvím Václavkovy ženy Jaroslavy.

„[...] Nejzajímavěji se ovšem rozvíjela otázka mé spolupráce s $B$. V., která se mi zdá dnes být dokonce spišse pritéžzi než kladem, nebo lépe řečeno, spiše stinnou stránkou mou než stránkou světlou. [...] Při předchozích prověrkách mi bývalo lidmi o hodně mladšimi vytýkáno, že se oháním B. V. a nebo, že zneuživám B. V. za zjištnými cíli, t. j. že velmi rafinovaně na B. V. vydělávám. [...] Situace se dnes opakuje a je zajímavé, kdo dnes zasel pochybnost o tom, zda mé styky

16 Archiv Národního muzea Praha, fond Robert Smetana, k. 8, inv. č. 618 - Václavek Bedřich 1932-1940. 
s B. V. byly solidní. Je to dr. Otakar Vašek, ${ }^{18}$ onen mladý profesor z Litovle, který Vás vr. 1938 navštěvoval a s nímž jsem se u Vás tehdy několikráte setkal. Za mé nepřitomnosti, t.j. po mém odchodu, upozornil na to, že jsem si s B. V. netykali, zatím co on si tykal, že jsem tam sice býval často (u Vás), ale B. V. že ke mně podle všeho neměl dưvěrný poměr atd. Z toho vznikl nyni takový obecný dojem, že jsem já nějak uměle a rafinovaně tady po Olomouci vytvořil vidinu o nějakém dìvěrném poméru $k$ B. V. a ted'že jsem byl odhalen. [...] Napiš mi nyni laskavě dalši odpovéd': Bylo toto netykáni mezi B. V. a mnou rozhodujicím znakem a bylo to netykáni se strany B. V. zámérné, či mělo to nějaký význam, co znamená jinými slovy: vylučoval mne tím B. V. z okruhu lidí, kterým dejme tomu důvěroval a znamená to tedy, že B. V. mne nedivvěroval a že by odpovídalo pravdě vice, kdybych dnes sebekriticky uznal, že B. V. Nespolupracoval se mnou, nýbrž že já jsem se vetřel $k$ Vám, do spolupráce s $B$. V., že jsem u Vás nebyl vitán a že se stalo jen mou nestydatostí, že jsem u Vás jedl a večeřel po leta, a u Vás také bydlil a jestli je to z méstrany omyl, považoval-li jsem se za-dejme tomu - př́slušníka rodiny? $[\ldots]^{* 19}$

Jaroslava Václavková pochopitelně tyto Smetanovy obavy vyvrátila a ujistila ho o opaku. Tomu nasvědčuje i bohatá dochovaná korespondence mezi Jaroslavou Václavkovou a Smetanou. Václavkova rodina Smetanovi obětavě pomáhala v době jeho studií, trávili společné prázdniny, přátelsky se navštěvovali. Smetana byl i několikrát povolán coby opatrovník psa Boba v době, kdy Václavkovi odjeli na dovolenou.

Přes řadu sběratelských a politických komplikací, se kterými se oba badatelé (a následně sám Smetana) potýkali, vedla jejich spolupráce $\mathrm{k}$ realizaci řady významných edičních i vědeckých projektů. ${ }^{20}$ Václavkův odkaz a dlouholetou společnou práci Robert Smetana utvrdil v roce 1955, kdy se rozhodl vydat jejich poslední společné dílo České světské písně zlidovělé, část epickou. Prakticky ve stejném období, v roce 1958, byl listem Tvorba, ${ }^{21}$ požádán, aby napsal př́spě-

18 Otakar Vašek (1910-1995) byl český a československý vysokoškolský funkcionár̆, politik Komunistické strany Československa. V roce 1948 byl zvolen do Národního shromáždění za KSČ ve volebním kraji Olomouc. V této funkci zůstal pouze rok. V letech 1953-1954 byl děkanem Fakulty společenských věd Vysoké školy pedagogické v Olomouci.

19 Archiv Národního muzea Praha, fond Robert Smetana, k. 8, inv. č. 621, Dr. Jaroslava Václavková.

20 České písně kramářské (1937); Český národní zpěvník (1940); Kritická edice Sušilovy sbírky Národní písně moravské (1941), kterou opatřili Doslovem; Kramářské písně (Ottův Slovník naučný nové doby, 1935); Pět českých lidových písní biblických (Sborník Bible a český národ 47, 1935); V práci pro lidovou píseň (Index 8, K 50. narozeninám Vladimíra Helferta, Olomouc 1936); Píseň o Theofilovi v kramářských písní - doplněk bibliografie, zvláštní otisk z časopisu Vlasteneckého musea v Olomouci, 1937); Ústní lidové podání melodie (Musikologie 1, 1938); Jak katalogizovali kramářské písně (s Bedřichem Václavkem, Janu Emlerovi k šedesátce, Praha 1938); Bedřich Václavek a český písňový folklór (B. Václavek: O lidové písni a slovesnosti, Praha 1963); O české písni lidové a zlidovělé (za spolupráce Roberta Smetany, Praha 1950); České světské písně zlidovělé (část I. Písně epické, 1955).

Tvorba: list pro kritiku a umění 
vek k 5. březnu $1943 .^{22}$ Smetana svým textem prakticky inicioval vznik konferencí s názvem Václavkova Olomouc. Sám k tomu uvedl: „[...] já jsem byl na takové podněty dost citlivý. V roce 1955 jsem totiž konečně vydal zlidovělou epiku (České světské písně zlidovělé, část I.: Písně epické) - její texty a nápěvy jsme sestavili v roce 1938! - a zbývala k zpracování ještè zlidovělá lyrika vlastenecká a milostná. K tomu jsme sice sebrali nějaký písňový materiál, ale už nezpracovali, takže na zpracování a vydání čekalo v těchto letech ještě 155 písní. A k tomu mi chyběl B. Václavek, a já tehdy nad tímto dopisem Tvorbě př̌šel na to, že bych měl využit Tvorby $k$ hledáni nějaké náhrady za B. Václavka. Napsal jsem tedy, že by se nad Václavkovým skonem nemělo truchlit, ale sejít se a dumat, co by se mělo dělat. Toho se chopil v Olomouci mládežník Jaromír Dvořák, ${ }^{23}$ přišel za mnou, cítil se zřejmě nějak ne dosti zaměstnán, a navrhl mi, abychom pořádali tato „,výročí" v Olomouci. Vyskytl se tam krom jiného taky Mirko Očadlík a navrhl, abychom tomu ř́kali ,Václavkova Olomouc ‘. [...]"24 Smetana založením konference doufal v nalezení nástupce Václavka a prímo psal, že předpokládal, že: „se lidé budou prát o Václavkovo místo", 25 ale neprali. Proto také Václavek nebyl nikým nahrazen a České světské písně zlidovělé zůstaly nedokončeny.

$*$

Zamyslíme-li se nad současnou reflexí Václavka a Smetany, dojdeme k závěru, že zatímco Václavkův odkaz je (i díky Smetanovi) literárními historiky reflektován, ${ }^{26}$ tak Smetanův odkaz, př́nos pro hudební vědu, město Olomouc a univerzitu je opomíjen. Ze sekundárních pramenů o Robertu Smetanovi totiž můžeme uvést pouze: dvě diplomové práce, ${ }^{27}$ vzpomínkové medailonky Smetanových kolegü ${ }^{28}$

Předpokládaný den úmrtí Bedřicha Václavka.

Významný český literární historik, zabývající se dějinami nové české literatury. Badatelský zájem směřoval k osobě Zdeňka Nejedlého.

Archiv Národního muzea Praha, fond Robert Smetana, inv. č. 1024, Kultura v Olomouci před a po okupaci (projev na veřejné plenární schůzi KSČ v Olomouci 25. 1. 1963), 15+7, strojopis.

Ibidem

I přesto, že je Václavkova pozůstalost stále literárními historiky v Památníku národního písemnictví nezpracována!

FIALOVÁ, Ivana. Robert Smetana - život a dílo. Diplomová práce, Pedagogická fakulta. Olomouc 1992; DOLÁKOVÁ, Markéta. Robert Smetana a jeho působení v oblasti muzejnictví a památkové péče v Olomouci v letech 1936-1946. Diplomová práce. Filozofická fakulta. Olomouc 2011. Především práce Markéty Dolákové. Ta připomněla především Smetanův př́nosem v oblasti muzejnictví, tedy oblasti, kterou zahájil svoji pracovní dráhu v Olomouci - oboru, ve kterém aktivně působil 10 let (1936-1946). Tuto práci můžeme současně chápat i jako navázání na článek, který vyšel v roce 1994 v Hanáckých novinách, který si jako první významněji povšimnul Smetanova působení v této oblasti. V době vzniku této studie vyšla na JAMU kniha Hudební život v meziválečném Brně ve vzpomínkách Roberta Smetany. Editorem je Josef Kovalčuk. Jedná se pouze o otištěné vzpomínky Smetany. Ed. Kovalčuk, Josef: Hudební život v meziválečném Brně ve vzpomínkách Roberta Smetany. Janáčkova akademie múzických umění v Brně. 2014

HUDEC, Vladimír. Jubileum Roberta Smetany, Hudebni věda, XVI, č. 3, 1979, str. 287-288; 
a sborník z muzikologické konference pořádané v Olomouci v roce $2004 .{ }^{29}$ To je prakticky vše. $Z$ uvedeného výčtu sekundárních pramenů pak nabýváme velmi zkreslených dojmů a informací, které se týkají Roberta Smetany a Olomouce. Až na základě primárních pramenů, které se nachází ve Smetanově pozůstalosti, se dozvíme skutečný Smetanův postoj k Olomouci, univerzitě a olomouckému regionu. Historiky jsou jeho kritické reflexe k městu „Velká Olomouc“ přecházeny a naopak a pochopitelně je připomínána pouze jeho snaha o zkulturnění této bývalé vojenské pevnosti. ${ }^{30}$

V jeho pozůstalosti nalezneme řadu cenného materiálu, kde Smetana popisuje svoje dojmy a stav města po svém prŕíchodu v roce 1935. Snažil se „marně pochopit tzv. Velkou Olomouc“, kde „,novodobá německá zástavba organicky navazovala na středověkou Olomouc“, zatímco ,pod okny finančních úradů na Palackého tř́dě bují bezostyšně v hanácké úrodné černozemi cukrová řepa a [...] padesát metrư pod náměstím Republiky [...] se vlni lány pšenice “. ${ }^{31}$ Ve svém textu Kultura v Olomouci z roku $1965^{32}$ parafrázuje dojmy Bedřicha Václavka „Když

HUDEC, Vladimír. K sedmdesátinám Roberta Smetany, Hudebni věda XII, č. 1, 1975, str. 92-93; HUDEC, Vladimír. Robert Smetana osmdesátiletý, Hudebni věda XXII, č. 2, 1985, str. 191-192; VIČAR, Jan. Za Robertem Smetanou, Hudebni rozhledy XLII, č. 1, 1989, str. 9-10.

29 Kritické edice Hudebních památek. Hudba v Olomouci. Historie a současnost II. In honorem Robert Smetana. Olomouc 2004.

30, „...] Olomouc byla vyřazena anebo vychýlena z normálního vývoje velikého městského sídliště v polovici 18. století, kdy přibližně třicetitisícové město bylo obehnáno ohromnými pevnostními valy tereziánské pevnosti a kdy olomoucká předměstí, vyrostlá organicky v bezprostředni blizkosti města, byla zbořena vybudována nově tak daleko od pevnosti, že před hradbami pevnosti vzniklo volné a dostatečně veliké pevnostni predpolí. Po zrušeni pevnosti v roce 1886 byla Olomouc městem bez periférie a městem, které bylo odděleno od nejbližšich vesnických sídlišt širokým pásem vysoce hodnotných polí a roli [...]“. Archiv Národního muzea, fond Robert Smetana, k. 21, inv. č. 1024, Kultura v Olomouci před a po okupaci (projev na veřejné plenární schůzi KSČ v Olomouci 25. 1. 1963). Termín „Velká Olomouc“ byl ale užíván už dřive v roce 1918. V místním tisku o ní mluví Adolf Kubis. „Podnikáme prvé kroky pro útvar velikého Olomouce, jenž by sepjal v jednu komunu všechna přilehlá předměstí k němu tíhnoucí a vytvořil tak po Brně a Moravské Ostravě třetí velké město moravské. Podle něj měla mít „Velký Olomouc“ většinu českého obyvatelstva, a podle toho „...bude třeba zařizovati budouci náš postup. Velký Olomouc bude a musí být český. "Výběr obcí, které se měly stát městskými částmi Olomouce, patrně usnadnil starší zemský zákon z roku 1904, který rozšiřoval působení městského stavebního úřadu v Olomouci i na Novou Ulici, Řepčín, Hejčín, Lazce, Neředín, Povel, Novosady, Klášterní Hradisko a na části Hodolan, Bělidel a Pavlovic až po koleje železničních tratí Olomouc - Česká Třebová a Olomouc - Prostějov. Osnovatelé budoucího sloučení však do svých plánů pro lepší výsledek připočítali ještě území Černovíra a zejména ryze české Chválkovice, také Nový Svět a Holici. První den po vánočních svátcích roku 1918 byli představitelé všech těchto obcí pozváni vládním komisařem Richardem Fischerem na radnici k první z řady dalších pracovních porad. Vychází z: TICHÁK, Milan: Velký Olomouc slaví 90 let. Jak a proč vznikl? [online]. 2009. [cit. 18. 1. 2015]. Dostupné z: http:// olomoucky.denik.cz/zpravy_region/velky-olomouc--jak-a-proc-vznikl-slavi-20090329.html

31 Archiv národního muzea Praha, fond Robert Smetana, k. 1, inv. č. 12, Paměti (strojopis), str. 32,42 .

32 Archiv národního muzea Praha, fond Robert Smetana, k. 21, inv. č. 1024, Kultura v Olomou- 
se komisař brněnské universitní knihovny dr. Bedřich Václavek přestěhoval $v r$. 1933 do Olomouce, střetávala se tu jeho pozornost s celou radou neobvyklých věci a okolností. Odhlédneme-li od osobnich problémů a záležitostí, které v životě Václavkově vyvolal odchod z Brna byly to hlavně na jedné straně obyvatelé Olomouce a na druhé straně jejich životni styl a životni podminky, které poutaly jeho pozornost a které jej zaměstnávaly [...] Václavek přišel do Olomouce po filosofických studiich v Praze, Vídni a v Berlině a po bezmála desítiletém pưsobení $v$ dělnickém Brně, se v Olomouci vyrovnával predevším s onou zvláštní atmosférou ticha a klidu, kterou se Olomouc třicátých let už na prvý pohled lišila od rušného a moderního [...] Brna. V Olomouci těchto let jakoby byl čas plynul pomaleji nežjinde ve světě a Olomouc délala na brněnského přistěhovalce znovu a znovu dojem, jakoby to byl jakýsi starý svět s mnoha starými věcmi, ve kterém se lidé starali dokonce i o to, aby i nové věci v Olomouci nerušily starosvětský ráz města a aby vypadaly staře." 33

Kritický postoj k městu nezastával jen Smetana nebo Václavek. Nutnost modernizace byla vnímána také mnohými dalšími. Např́iklad redaktor deníku Pozor na anketu starosty Richarda Fischera „Co Olomouc potřebuje a jak toho dosáhne?" z počátku roku 1937 odpověděl: „Potřebuje se zbavit lidí bezduchých, parasitư, či laciných kritiků, lidí, důležitých', $k$ slávě a dějinám Olomonce chladných a proto od prípadu k př́padu klopýtajicich, chlebickujicich, nebo padesáti funkcemi ve všech možných spolcích zmožených pánů. Ano, potřebujeme v Olomouci lidi, kteří, jak jsem již několikráte psal, dovedou pochopit mozkem i duši postaveni Olomouce, kteři se dovedou probit čestně, s otevřeným hledím nepřizní těch laciných kritikư “. ${ }^{34}$ Podobný názor zveřejnil i Moravský večerník: „Co by tudiž Olomouc v prvé radě potrebovala“ ${ }^{35}$ Výčet negativních jevů, které Smetana v Olomouci hlavně zpočátku vnímal, lze uzavřít jeho podobně vyznívající myšlenkou: „Olomoučanưm stačilo $k$ dokonale spokojenému životu to, co tu zanechala minulost, [...] znovu se vyjevovalo, že vývojově ustrnulé prostředí, město bez modernizujicich potřeb a sil [...] u svých obyvatel [...] plodí také vysloveně negativni společenské vlastnosti a maloměštáctvi se všemi jeho zly." ${ }^{\text {36 }}$

Přes množství výtek, které Robert Smetana mnohokrát zmiňoval, byla jeho snaha o pokrok v kontextu historie, kultury a doby neúnavná. „Neni pochyby o tom, že pochopeni historického vývoje našich zemí a měst může nám v mnohém napomoci $k$ tomu, abychom se správně a účelně orientovali v současném životě. Jde tedy o to, abychom se v budoucnosti snažili odstranit ono vychýleni vývoje

ci před a po okupaci (projev na veřejné plenární schůzi KSČ v Olomouci 25. 1. 1963), 15+7, strojopis.

34 FISCHER, Richard. Šest let práce (1932-1938) na olomoucké radnici, Olomouc 1938, str. 90.

Ibidem, s. 94.

Archiv národního muzea Praha, fond Robert Smetana, k. 8, inv. č. 618, opis Václavkova dopisu z 21. 10. 1935. 
Olomouce, $k$ němuž došlo v čtyřicátých letech 18. století a abychom rozvoj života v Olomouci zakládali v dostatečné míre na rozvoji práce a výroby. "37 Smetana viděl vzrůst úrovně města především v obnovení vysokého školství v Olomouci. „A nikoli bez důležitosti je konečně $i$ okolnost, že obnovená universita rozrušila klid a nečinnost onoho zubem času značně už sešlého eráru, kléru [...] a že Olomouci byl takto vrácen alespoň zčásti jeji pưvodni význam mistní, celostátní a snad i mezinárodní. [...]“38

Smetana dovedl ocenit uměleckohistorický potenciál města a svojí činností se zasloužil o vzrůst celkové úrovně města $\mathrm{i}$ jeho obyvatel. Aktivně se zapojil do protestu o zrušení místního denního tisku. Po územní reorganizaci v roce 1960 byla i Olomouc jako okresní město zbavena všeho místního denního tisku, aniž se přihlíželo $\mathrm{k}$ tomu, že Olomouc byla sedmým největším městem v republice. „[...] Zrušením denního tisku v Olomouci [...] došlo $k$ nezodpovédnému ochuzení veřejného života a snižení politického a kulturního dění v nejlepšim slova smyslu ve významné československé kulturní oblasti. [...] [39 Jeho aktivity s tímto městem jsou dále patrné např́klad v článcích $O$ akčním programu pro Olomouc, O zvláśtním postaveni kulturní problematiky v olomouckém okresu, nebo například Jak dál v kultuře na Olomoucku. ${ }^{40}$

Bedřich Václavek nebyl nikdy nadšeným obdivovatelem města Olomouce. Svůj pobyt zde mnohokrát označil za nedobrovolný. Smetana, i přes počáteční rozpaky a nechut' v Olomouci zůstal, našel v hanácké metropoli jednak první zaměstnání, tak se stal aktivním členem týmu pro znovuobnovení vysokého školství v Olomouci a zakladatelem zdejšího hudebně-vědného pracoviště. Tomu dokázal vtisknout specifickou profilaci spočívající především v rozšiřrení badatelského zájmu v oblasti folkloristiky, lidové hudby či regionalistiky - právě ta je i v současné době zastoupena nejvíce. V roce 1949 se podílel na vybudování Divadla hudby Olomouc, které mělo fungovat jako př́pravna pro studentskou popularizační činnost. ${ }^{41} \mathrm{~V}$ roce 1958 inicioval vznik uměnovědných konferencí pod názvem Václavkova Olomouc. Tyto konference se pak od roku 1960 konaly pravidelně. S životem a dílem Bedřicha Václavka byl spojen, a to nejen kvưli předmětu svého badatelského zájmu, prakticky celý život. Po vydání první části světských písní se Smetana k jejich pokračování nedostal, ale nadále se problematikou lidového zpěvu a české folkloristiky zabýval, ale již pouze teoreticky

37 Archiv národního muzea Praha, fond Robert Smetana, k. 30, inv. č. 1153, Kultura v Olomouc před a po okupaci.

38 Ibidem.

39 Kultura a universita v Olomouci 16. 5. 1966; Obrázková knížka o U. P. v Olomouci, opis 1, 19. 7.1968

40 Archiv národní muzea Praha, fond Robert Smetana, k. 18, inv. č. 1062, Dvě olomoucké okupační památkářské vzpomínky (článek pro archivní sborník, zasláno dr. Spáčilovi) + průvodní dopis.; Kultura a universita v Olomouci 16. 5. 1966; Obrázková knížka o U. P. v Olomouci, opis 1, 19. 7. 1968, Archívní exemplář plán a jeho rozpis.

Po vzoru pražského Divadla hudby. 
- ostatně sám sebe nikdy neoznačoval za folkloristu, nýbrž muzikologa, který z tohoto pohledu studoval lidový zpěv. Jako významný počin, pomyslně završující spolupráci mezi ním a Václavkem, je jeho text Hudební vývoj a jeho členění. Teze k periodizaci dějin hudby, ${ }^{42} \mathrm{kdy}$ rozšíríl slavnou helfertovskou periodizaci dějin hudby o hudbu českou a především o problematiku lidové písně a hudby v hudebně historickém vývoji.

Tato studie odkrývá sondu do osobního a společenského života dvou významných vědců $\mathrm{v}$ kontextu prvorepublikového a protektorátního období. To vše na pozadí vzniku důležitých jevů, které dnes pokládáme za samožrejmé, a které v určité době samozřejmé nebyly. Poukazuje na to, na kolik je člověk schopen změnit situaci v maloměštácké Olomouci. Odkrývá impulsy vzniku vědecké, popularizační a historicko-komparativní činnosti v tomto univerzitním městě.

Pavlína Kráčmarová (Kracmarovapavlina@seznam.cz), Katedra muzikologie, Filozofická fakulta, Univerzita Palackého, Olomouc.

\section{ABSTRACT \\ ROBERT SMETANA AND BEDŘICH VÁCLAVEK AND THEIR COOPERATION IN THE CONTEXT OF THE TIME AND PLACE. THE EXCERPTS OF ONE LIFE CHARTER}

This study consists of the following three parts: Robert Smetana and Bedřich Václavek, cooperation and personal relationships; Robert Smetana and Olomouc, comparison with the views of Bedřich Václavek; final summary. This work presents, in its first part, an unpublished letter and comments on this cooperation and on a personal level. In the second part of the text, we show as it looked Olomouc on the period the First Republic and the Protectorate. At the end, we briefly compares importace of Robert Smetana and Bedřich Václavek for town Olomouc and university.

\section{Key words}

Robert Smetana, Bedřich Václavek, Olomouc, musicology, folklore

\section{Bibliography}

\section{Sources}

Archiv národní muzea Praha, fond Robert Smetana, k. 18, inv. č. 1062, Dvě olomoucké okupační památkářské vzpomínky (článek pro archivní sborník, zasláno dr. Spáčilovi) + průvodní dopis.

Archiv Národního muzea Praha, fond Robert Smetana, k. 8, inv. č. 618 - Václavek Bedřich 1932 1940.

Archiv národního muzea Praha, fond Robert Smetana, k. 1, inv. č. 12, Paměti (strojopis), str. 32, 42. Archiv národního muzea Praha, fond Robert Smetana, k. 21, inv. č. 1024, Kultura v Olomouci před a po okupaci (projev na veřejné plenární schůzi KSČ v Olomouci 25. 1. 1963), 15+7, strojopis. Archiv Národního muzea Praha, fond Robert Smetana, k. 8, inv. č. 621, Dr. Jaroslava Václavková. 
Památník národního písemnictví Praha, fond Bedřich Václavek, nezpracovaná pozůstalost. Oddíl Smetana Robert.

\section{Literature}

DOLÁKOVÁ, Markéta. Robert Smetana a jeho působení v oblasti muzejnictví a památkové péče v Olomouci v letech 1936-1946. Diplomová práce. Filozofická fakulta. Olomouc 2011. BUREŠOVÁ, Alena (ed.). Kritické edice Hudebních památek. Hudba v Olomouci. Historie a současnost II. In honorem Robert Smetana. Olomouc 2004.

FIALOVÁ, Ivana. Robert Smetana - život a dílo. Diplomová práce, Pedagogická fakulta. Olomouc 1992

FISCHER, Richard. Šest let práce (1932-1938) na olomoucké radnici, Olomouc 1938, str. 90 HOMOLKA, František. Rozšíření písní umělých mezi lidem českým. Český lid, 1911, r. 20, str. $31-41$

HUDEC, Vladimír. Jubileum Roberta Smetany, Hudebni věda, XVI, č. 3, 1979, str. 287-288

HUDEC, Vladimír. K sedmdesátinám Roberta Smetany, Hudební věda XII, č. 1, 1975, str. 92-93

HUDEC, Vladimír. Robert Smetana osmdesátiletý, Hudebni věda XXII, č. 2, 1985, str. 191-192

TICHÁK, Milan. Velký Olomouc slaví 90 let. Jak a proč vznikl? [online]. 2009. [cit. 18. 1. 2015]. Dostupné z: http://olomoucky.denik.cz/zpravy_region/velky-olomouc--jak-a-proc-vznikl-slavi-20090329.html

VIČAR, Jan. Za Robertem Smetanou, Hudební rozhledy XLII, č. 1, 1989, str. 9-10

VIČAROVÁ, Eva. Robert Smetana. [online]. 2010. [cit. 18. 1. 2015]. Dostupné z: http://www. ceskyhudebnislovnik.cz/slovnik/index.php?option=com_mdictionary\&action=record_detai$1 \& \mathrm{id}=783$ 